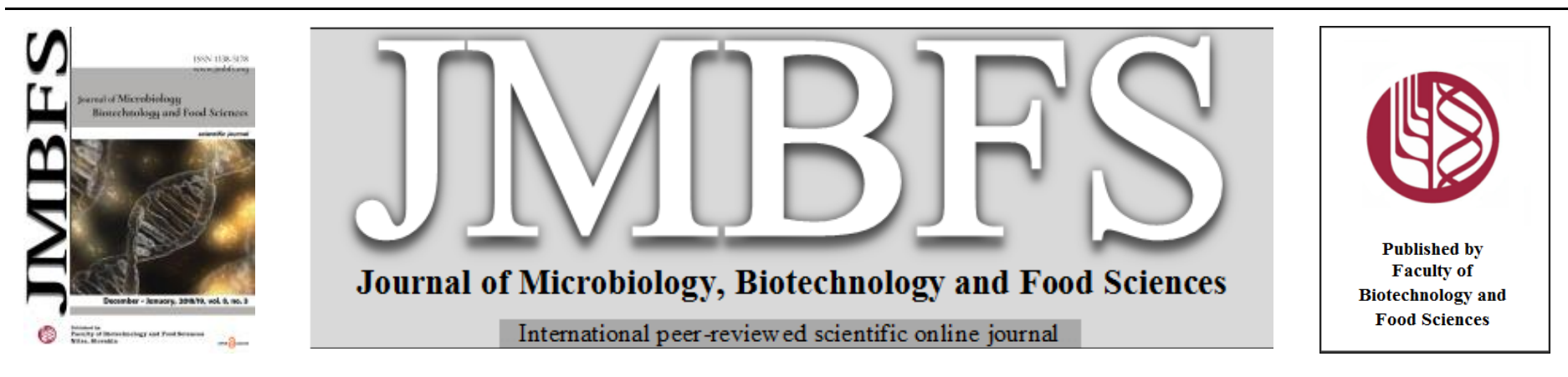

\title{
EVALUATION OF THE GLUTEN-FREE BAKERY PRODUCTS CONSUMPTION IN RELATION TO HYPERTENSION AS RISK FACTOR FOR CARDIOVASCULAR DISEASE
}

\author{
Anna Kolesárová*1, Martina Gažarová2, Jana Kopčeková , Jana Mrázová ${ }^{2}$, Lucia Zeleňáková3 \\ Address(es): Ing., PhD. Anna Kolesárová \\ ${ }^{1}$ Department of Plant Products Storage and Processing, Faculty of Biotechnology and Food Sciences, Tr. A. Hlinku 2, 949 76, Slovak University of Agriculture in \\ Nitra. \\ ${ }^{2}$ Department of Human Nutrition, Faculty of Agrobiology and Food Resources, Tr. A. Hlinku 2, 949 76, Slovak University of Agriculture in Nitra. \\ ${ }^{3}$ Department of Food Hygiene and Safety, Faculty of Biotechnology and Food Sciences, Tr. A. Hlinku 2, 949 76, Slovak University of Agriculture in Nitra.
}

*Corresponding author: anna.kolesarova@uniag.sk

doi: 10.15414/jmbfs.2018-19.8.3.920-924

ARTICLE INFO

Received 19. 6. 2018

Revised 30. 9. 2018

Accepted 1. 10. 2018

Published 1. 12. 2018

Regular article

open $\partial_{\text {ACCESS }}$

\begin{abstract}
The gluten-free products market represents one of the most prosperous markets in the field of food and beverages in the immediate future. The aim of our study was to evaluate the effect of the gluten-free bakery products consumption on hypertension development as risk factor for cardiovascular disease. The study group was composed of volunteers from the general population and consisted of thirty healthy adults. The amount of bakery product for consumption was determined as follows: women consumed 150-200 grams per day; men 200-250 grams per day. There was no evidence of moderate or severe hypertension in our study, and this did not change during the whole research period. We found that six-week consumption of gluten-free bread and bakery products had a non-significant effect on reducing blood pressure as the major risk factor for cardiovascular disease. The most significant decrease of blood pressure was recorded with a two-month pause (after the immediate end of consumption of gluten-free bakery products), where we found a statistically significant $(P<0.05)$ decrease in both systolic and diastolic blood pressure values compared to baseline. On average, the pulse rate varied during the study without significant differences from the initial value. We found significant reductions in serum sodium and chloride levels and a significant increase in blood serum potassium level $(P<0.001)$ after six weeks of consumption of gluten-free bakery products. Two months after the gluten-free bakery product was consumed we found a significant increase in sodium, chloride and potassium levels opposite the first measurement $(P<0.001)$. All participants had optimal sodium levels. We can summarize that dietary habits play a crucial role in the development of hypertension and the consumption of bread and bakery products can also affect it. However, the overall effect of bread and bakery consumption on the hypertension development depends on many factors, such as the composition of the bread and bakery products and the presence of gluten.
\end{abstract}

Keywords: gluten-free bakery products, hypertension, blood pressure, sodium, potassium

\section{INTRODUCTION}

Celiac disease is a lifelong autoimmune disorder caused by permanent intolerance to gluten, which affects the small intestine and immune system in genetically predisposed individuals. Celiac disease can be diagnosed at any age (Suchá et al., 2015). Individuals with celiac disease (CD) show high levels of intestinal inflammation when exposed to gluten-containing foods (Ludvigsson $\boldsymbol{e}$ al., 2013). Clinically, as direct response to gluten and related prolamines in a diet, immunological processes damage intestinal mucosa and lead to villous atrophy, crypt hyperplasia and nutrient malabsorption (Husby et al., 2012). CD occurs in $1 \%$ of the population in Europe and the United States, induced by an environmental precipitant, gluten in genetically susceptible person. In Slovakia, the incidence of celiac disease is 1:250. Prevalence is more pronounced in women with a ratio of 2:1 to 3:1 (Grace-Farfaglia, 2015; Suchá et al., 2015). Since the ingestion of gluten leads to inflammation and mucosal damage in the small intestine, resulting inmalabsorption of micronutrients such as iron, folic acid, calcium and fat-soluble vitamins, the only treatment is strict adherence to a lifelong gluten-free diet (GFD) (Gujral et al., 2012; Brites et al., 2018). For CD patients, adhering to a restrictive GF diet can be challenging because cereal products are staple foods in western countries and play a predominant role in a regular diet (e.g. bread or pasta) and a wide range of processed foods contain gluten-based products as additional ingredients (Mulder et al., 2015). Bread is one of the most popular baked products consumed as staple food in many countries (Taylor and Rosell, 2016). In recent years, gluten-free (GF) goods have become popular, fuelling a growing market, as they not only cater to individuals with medical needs but also to consumers who seek a GF diet (Pellegrini and Agostoni, 2015). Originally developed specifically for coeliac, gluten-free foods have become trendy among sections of the wider population, thanks in part to celebrity endorsement (Buttriss, 2017). Adoption of a glutenfree diet by people without celiac disease rose more than threefold from 2009-10 (prevalence 0.52\%) to 2013-14 (prevalence 1.69\%) (Kim et al., 2016). In fact, basing on incorrect information, people not suffering from CD may either think that these products are healthier than conventional products, or feel they are helpful for weight loss programmes (Miranda et al., 2014). The overall effect of bread and bakery consumption on the development of overweight depends on many factors, such as the composition of the bread and bakery products and the presence of gluten (Gažarová et al., 2018). A paper in The BMJ advises that promotion of gluten-free diets among people without coeliac disease should not be encouraged because avoidance of gluten may result in reduced consumption of beneficial wholegrains. These, and wholemeal products made from them, are associated with lower cardiovascular risk (Buttriss, 2017). Notwithstanding a growth in popularity and consumption of GF food products, there is a lack of substantiated analysis of the nutritional quality compared with their glutencontaining counterparts. For GF foods no predominant health benefits are indicated; in fact, some critical nutrients must be considered when being on a GF diet (Missbach et al., 2015). The consumption of GF products is unlikely to confer health benefits, unless there is clear evidence of gluten intolerance (Wu $\boldsymbol{e t}$ al., 2015). Several GF foodstuffs contain more fat, including saturated, and salt but fewer minerals and vitamins than their equivalents with gluten (Pellegrini and Agostoni, 2015). The content of potassium, phosphorus, calcium, iron, zinc and B vitamins of almost all types of GF bread and pasta samples considered is lower than that in the conventional products (European Institute of Oncology, 2008). Moreover, particular attention should be paid to the high sodium content of some products. Only 14 out of $60 \mathrm{GF}$ products considered can be classified as 
'a food with a low sodium content' ( $<120 \mathrm{mg}$ per $100 \mathrm{~g}$ ) (Parlamento Europeo e Del Consiglio, Regolamento, 2006). Miranda et al. (2014) showed that pasta and bakery products had more sodium than their equivalent products containing gluten. The high content of sodium in several GF products, especially in bakery products, is useful for stabilising the structure and enhancing the taste and flavour, mainly in the products in which the first ingredient is the tasteless starches. Other authors report that in the case of breads bread and bakery products, sodium content was lower in GF products $(388.4 \pm 206.4 \mathrm{mg} / 100 \mathrm{~g})$ compared to gluten-containing foods $(581.9 \pm 290.3 \mathrm{mg} / 100 \mathrm{~g} ; \mathrm{F}=4.5 ; \mathrm{p}<0.05)$ Across all other categories, sodium content did not differ significantly (Missbach et al., 2015).

Increased consumption of dietary sodium is a leading cause of cardiovascular disease (CVD) and hypertension and has also been linked to an increased risk of stroke, stomach cancer, kidney disease and bone demineralization (Wardener and MacGregor, 2002). According to the American Heart Association CVD and stroke are the first and second-leading global causes of death which, together with their related diseases, account for 17.3 million deaths per year (Mozaffarian et al., 2015). High blood pressure has been noted as one of the major modifiable factors in the development of CVD (He and MacGregor, 2008). Thus limitations on sodium $(\mathrm{Na})$ consumption were recommended by the WHO and further international health agencies ( $<2 \mathrm{~g} \mathrm{Na}$ per day). Bread and other cereal products contribute about $30 \%$ to the daily intake of sodium in the western human diet (Silow et al., 2016). Sodium chloride $(\mathrm{NaCl})$ is composed of sodium $\left(\mathrm{Na}^{+}\right)$and chloride $\left(\mathrm{Cl}^{-}\right)$ions joined by an ionic bond. Sodium chloride is essential for life and is better known as (table) salt. Throughout the following review, the terms 'salt' and 'sodium chloride' are not synonymous with the term 'sodium'. For the conversion of sodium into sodium chloride its weight must be multiplied by 2.54 (Silow et al., 2016). In contrast to the WHO advice, in 2010 the global mean sodium intake was $3.95 \mathrm{~g}$ per day (10.06 g per day of salt), nearly twice the WHO recommended limit (Powles et al., 2013). Generally, many food additives contain sodium such as baking powder and soda which are used as leavening agents in various baked goods. Furthermore, sodium chloride is added to bakery products to improve taste, flavour and aroma (Cauvain, 2007) Moreover, it plays a vital role in processing by improving textural properties and water binding capacity of the dough (Beck et al., 2012). Sodium chloride also acts as a preservative against microbial spoilage by reducing the water activity (Hutton, 2002). Epidemiological studies show an inverse correlation between blood-pressure levels and potassium intake. Almost all of the intervention trials performed have shown a significant reduction in systolic and diastolic blood pressure with potassium supplementation. The relationship of blood pressure to CVD risk is important with respect to potential preventive nutritional strategies. The well-known roles of ions such as sodium, potassium, calcium, magnesium and chloride in regulating blood volume, vascular tone and membrane ionchannel activity also indicate the potential role of micronutrients as well as macronutrients in blood-pressure regulation (Riccardi et al., 2011).

Our study was mainly focused on the effect of six weeks consumption of glutenfree bread and bakery products on changes in systolic and diastolic blood pressure, pulse and the sodium, potassium and chloride levels in blood serum. Simultaneously, we assessed the changes of these parameters two months after the termination of the consumption of gluten-free bakery products.

\section{MATERIAL AND METHODS}

\section{Characteristics of the participants}

The trial was approved by the Ethic Committee at the Specialized Hospital St. Zoerardus Zobor, n.o. (protocol no. 012911/2016). The requirement for participation in the research was informed consent of volunteers with all the study and measurement conditions which they will have to complete during the research. All participants signed written informed consent to participate in the study. The participant group was composed of volunteers from the general population and consisted of 30 healthy adults ( 3 men and 27 women), who during 6 -week period consumed gluten-free bread and gluten-free bakery products, however the participant of the study were not allowed total gluten-free diet Participants with the present severe disease or with recommended special dietary regimen were excluded from the study group. The amount of bread and bakery products was determined according to the recommended consumption of food for the Slovak population as follows: women consumed 150-200 grams per day; men 200-250 grams per day. All participants were asked not to change their eating habits and also not to change their habits related to the physical activity. Probands had a total of 3 measurements (first measurement before consumption of gluten-free bakery products, second measurement after the 6-week consumption of gluten-free bread and bakery products, and the third measurement 2 months after end of consuming gluten-free bakery products).

\section{Dietary Assessment}

We used the Mountberry - Nutrition \& Fitness Software (2011, Version 1.1) to evaluate the 3-days nutritional protocols (two weekdays and one weekend day) of study participants. Mountberry provides a complete analysis of food, meals, recipes based on an updated food database and nutritional recommendations for nutrient intake, health insights, dietary guidelines, and individual user needs. At work we focused on basic parameters such as energy, proteins, carbohydrates, fats and also minerals (potassium and sodium).

\section{Measurement of blood pressure}

Blood pressure was measured by using OMRON Microlife AG, 9443 (Widnau/Switzerland) with fully automatic operation and the possibility of using both the classic and elongated inflatable cuff on the shoulder. Blood pressure was measured after the body fluid had settled, resting, sitting. Systolic and diastolic blood pressure and pulse were measured. The reference limits were: for systolic pressure $120-129 \mathrm{mmHg}$, diastolic pressure $80-84 \mathrm{mmHg}$ and pulse $60-90$ beats per minute.

\section{Blood samples}

Blood samples were obtained before the start of consumption, after 6 weeks of consumption, and 8 weeks after end of consumption. Venous blood was collected in the morning after $8 \mathrm{~h}$ of fasting using $2.5 \mathrm{~mL}$ EDTA solution and in a $2 \times 7.5$ $\mathrm{mL}$ serum gel tube. After the separation of blood serum, the sodium, potassium and chloride levels were measured by automatic biochemical analyser Biolis $24 \mathrm{i}$ Premium (Tokyo Boeki Machinery Ltd., Japan) using direct ion selective electrodes methods in the laboratories of the Department of Clinical Biochemistry of the Specialized Hospital St. Zoerardus Zobor.

\section{Statistical analysis}

We evaluated the collected data from the measurements statistically and graphically in Microsoft Office Excel 2010 (Los Angeles, CA, USA). The changes in different groups were performed using Pared Student $t$-test and the data were presented as mean \pm standard deviation (SD). The levels of statistical significance were set at $P<0.05(*), P<0.01(* *), P<0.001(* * *)$.

\section{RESULTS AND DISCUSSION}

\section{Blood pressure (BP)}

Hypertension is a persistent elevation of systolic blood pressure of $\geq 140 \mathrm{mmHg}$ and a diastolic blood pressure of $\geq 90 \mathrm{mmHg}$. Hypertension is the 'silent killer' as it occurs with no warning signs or symptoms; it is regarded as one of the main causes of early death (Pitchai et al., 2016). Tab. 1 shows the distribution of participants according to their systolic and diastolic blood pressure values during the study. At the beginning of the study we found normal systolic blood pressure $(40 \%)$ and normal diastolic blood pressure $(50 \%)$ in most people under investigation. After six weeks of gluten-free bakery products consumption the number of subjects with optimal systolic blood pressure increased to $50 \%$ with an average of $113 \mathrm{mmHg}$ and the number of subjects with optimal diastolic blood pressure increased to $56.7 \%$ with a pressure of $72 \mathrm{mmHg}$. There was no evidence of moderate or severe hypertension in our study, and this did not change during the whole research period.

Table 1 Representation of participants in categories during study

\begin{tabular}{|c|c|c|c|c|c|c|c|}
\hline \multirow{2}{*}{ Systolic blood pressure } & & \multicolumn{2}{|c|}{ baseline } & \multicolumn{2}{|c|}{$\begin{array}{l}\text { after } 6 \text { weeks of } \\
\text { consumption }\end{array}$} & \multicolumn{2}{|c|}{$\begin{array}{l}2 \text { months after end } \\
\text { of consumption }\end{array}$} \\
\hline & & $\mathbf{n}$ & mean & $\mathbf{n}$ & mean & $\mathbf{n}$ & mean \\
\hline Normal & $<120 \mathrm{mmHg}$ & 12 & 112 & 15 & 113 & 17 & 111 \\
\hline Prehypertension - high normal & $120-129 \mathrm{mmHg}$ & 12 & 125 & 8 & 124 & 7 & 123 \\
\hline Prehypertension - elevated & $130-139 \mathrm{mmHg}$ & 4 & 135 & 5 & 133 & 5 & 133 \\
\hline Stage 1 hypertension & $140-159 \mathrm{mmHg}$ & 2 & 147 & 2 & 147 & 1 & 142 \\
\hline Stage 2 hypertension & $160-179 \mathrm{mmHg}$ & 0 & - & 0 & - & 0 & - \\
\hline Hypertensive crises & $>180 \mathrm{mmHg}$ & 0 & - & 0 & - & 0 & - \\
\hline
\end{tabular}




\begin{tabular}{|c|c|c|c|c|c|c|c|}
\hline \multirow[t]{2}{*}{ Diastolic blood pressure } & & \multicolumn{2}{|c|}{ baseline } & \multicolumn{2}{|c|}{$\begin{array}{l}\text { after } 6 \text { weeks of } \\
\text { consumption }\end{array}$} & \multicolumn{2}{|c|}{$\begin{array}{l}2 \text { months after end } \\
\text { of consumption }\end{array}$} \\
\hline & & $\mathbf{n}$ & mean & $\mathbf{n}$ & mean & $\mathbf{n}$ & mean \\
\hline Normal & $<80 \mathrm{mmHg}$ & 15 & 71 & 17 & 72 & 22 & 72 \\
\hline Prehypertension - high normal & $80-84 \mathrm{mmHg}$ & 5 & 83 & 5 & 81 & 2 & 84 \\
\hline Prehypertension - elevated & $85-89 \mathrm{mmHg}$ & 5 & 86 & 3 & 86 & 4 & 87 \\
\hline Stage 1 hypertension & $90-99 \mathrm{mmHg}$ & 5 & 94 & 5 & 93 & 2 & 95 \\
\hline Stage 2 hypertension & $100-109 \mathrm{mmHg}$ & 0 & - & 0 & - & 0 & - \\
\hline Hypertensive crises & $>110 \mathrm{mmHg}$ & 0 & - & 0 & - & 0 & - \\
\hline \multirow[t]{2}{*}{ Pulse } & & \multicolumn{2}{|c|}{ baseline } & \multicolumn{2}{|c|}{$\begin{array}{l}\text { after } 6 \text { weeks of } \\
\text { consumption }\end{array}$} & \multicolumn{2}{|c|}{$\begin{array}{l}2 \text { months after end } \\
\text { of consumption }\end{array}$} \\
\hline & & $\mathbf{n}$ & beats & $\mathbf{n}$ & beats & n & beats \\
\hline$<60$ beats per minute & & 0 & - & 0 & - & 0 & - \\
\hline $60-90$ beats per minute & & 25 & 76 & 22 & 78 & 22 & 76 \\
\hline$>90$ beats per minute & & 5 & 101 & 8 & 100 & 8 & 101 \\
\hline
\end{tabular}

In Tab. 2 we express the mean values and other characteristics of systolic and diastolic blood pressure and the measured pulse in the dynamics of the study. The average values of both systolic and diastolic blood pressure were decreasing. The most significant changes were recorded with a two-month pause where we found a statistically significant $(P<0.05)$ decrease in both SBP and DBP values compared to the baseline. When comparing the baseline and endpoints it was shown that throughout the study the systolic blood pressure was reduced in 22 subjects with an average of $-7.6 \mathrm{mmHg}$ and diastolic in 16 probands of -8.2
$\mathrm{mmHg}$ and an increase in 8 subjects by an average of $6.1 \mathrm{mmHg}$ in the case of systolic blood pressure whereas the diastolic pressure had increased in 11 subjects by $3.6 \mathrm{mmHg}$. Three probands did not change their diastolic blood pressure at the end of the study compared to the baseline. On average, the pulse rate varied during the study without significant differences from the initial value of $79.93 \pm 11.84$ to $84.03 \pm 11.92$ until the final $82.67 \pm 13.34$ beats per minute.

Table 2 Changes of systolic and diastolic blood pressure and pulse during the trial

\begin{tabular}{|c|c|c|c|c|c|c|c|c|c|}
\hline & \multicolumn{2}{|c|}{$\begin{array}{l}\text { Systolic blood pressure } \\
(\mathrm{mmHg})\end{array}$} & & \multicolumn{2}{|c|}{$\begin{array}{l}\text { Diastolic blood pressure } \\
(\mathrm{mmHg})\end{array}$} & \multirow[b]{2}{*}{$\begin{array}{l}2 \quad \text { months } \\
\text { after end of } \\
\text { consumption }\end{array}$} & \multicolumn{2}{|c|}{$\begin{array}{l}\text { Pulse } \\
\text { (beats per minute) }\end{array}$} & \multirow[b]{2}{*}{$\begin{array}{l}2 \text { months } \\
\text { after end of } \\
\text { consumption }\end{array}$} \\
\hline & baseline & $\begin{array}{l}\text { after } \\
\text { weeks of } \\
\text { consumption }\end{array}$ & $\begin{array}{l}2 \text { months after } \\
\text { end of } \\
\text { consumption }\end{array}$ & baseline & $\begin{array}{l}\text { after } 6 \\
\text { weeks of } \\
\text { consumption }\end{array}$ & & baseline & $\begin{array}{l}\text { after } 6 \\
\text { weeks of } \\
\text { consumption }\end{array}$ & \\
\hline Mean & 122.60 & 121.33 & 118.67 & 79.30 & 78.43 & 76.27 & 79.93 & 84.03 & 82.67 \\
\hline \pm SD & 11.02 & 11.38 & 11.20 & 9.64 & 8.88 & 8.63 & 11.84 & 11.92 & 13.34 \\
\hline Max & 152.00 & 152.00 & 142.00 & 97.00 & 94.00 & 99.00 & 111.00 & 108.00 & 118.00 \\
\hline Min & 103.00 & 101.00 & 92.00 & 64.00 & 63.00 & 62.00 & 65.00 & 63.00 & 67.00 \\
\hline Mod & 117.00 & 120.00 & 115.00 & 74.00 & 81.00 & 74.00 & 73.00 & 82.00 & 77.00 \\
\hline Med & 121.50 & 119.50 & 118.50 & 80.00 & 78.00 & 74.50 & 77.00 & 82.50 & 78.00 \\
\hline$P$ & 0.2755 & 0.1141 & $0.0129 * \mathrm{a}$ & 0.4081 & 0.0802 & $0.0187 * \mathrm{a}$ & 0.0744 & 0.5136 & 0.2201 \\
\hline
\end{tabular}

Note: \pm SD - standard deviation; Max - maximum value; Min - minimum value; Med - the median value of a range of values; the levels of statistical significance chosen for the comparisons were $P<0.05(*), P<0.01(* *), P<0.001$ (***); a - differences between baseline data and post-intervention data.

With regard to changes in blood pressure, attention is drawn to the intake of minerals by food. Sodium and chloride, which are principal ions in extracellular fluid, which includes blood plasma, play a critical role in life-sustaining processes (Silow et al., 2016).

\section{Sodium}

Limitation of sodium chloride in food has historically been considered the critical change for reducing blood pressure. Changes in sodium intake do affect blood pressure in older persons and in patients with hypertension and diabetes, whereas its role in population blood pressure has proven controversial. Meta-analyses indicate that adequate intake of minerals, e.g. and probably calcium, rather than restriction of sodium, should be the focus of dietary recommendations (Hermansen, 2000). Epidemiological studies indicate a positive association between dietary salt intake, level of BP and prevalence of hypertension (Law, 1997). Table 3 shows the mean values of sodium, potassium and chloride from blood serum samples. In the first measurement, $76.6 \%$ of the tested subjects had normal sodium levels $\left(135-145 \mathrm{mmol}^{-1}\right)$ and $23.3 \%$ had hyponatraemia $(<135$ mmol. $\left.1^{-1}\right)$. The low chloride level was found in $93.3 \%$ of the investigated subjects and only $6.7 \%$ of the participants had the level of chlorides in the range of normal values. After 6 weeks of consumption of gluten-free bakery products, we recorded a decrease in the mean sodium and chloride levels compared to the first blood test $(P<0.001)$. The number of people with hyponatraemia $(76.6 \%)$ and the number of people with low chloride $(86.7 \%)$ was increased. Two months after end the GF bakery product was consumed, we found a significant increase in sodium and chloride levels opposite the first sampling and also in the 6-week consumption of GF bakery products $(P<0.001)$. All volunteers had reference sodium levels. In the case of chlorides, the number of low-level persons $(33.3 \%)$ decreased and the number of people with normal chloride levels $(63.3 \%)$ increased. One subject had increased its chloride level above the standard $(>106$ mmol. $1^{-1}$ ).

Table 3 Changes of sodium, potassium and chlorides levels during the trial

\begin{tabular}{|c|c|c|c|c|c|c|c|c|c|}
\hline & \multicolumn{3}{|c|}{ Sodium $\left(\right.$ mmol..$\left.^{-1}\right)$} & \multicolumn{3}{|c|}{ Potassium $\left(\mathrm{mmol.}^{-\mathbf{1}}\right)$} & \multicolumn{3}{|c|}{ Chlorides $\left(\mathrm{mmol}^{-1} \mathrm{I}^{-1}\right)$} \\
\hline & baseline & $\begin{array}{l}\text { after } 6 \text { weeks } \\
\text { of } \\
\text { consumption }\end{array}$ & $\begin{array}{l}2 \text { months } \\
\text { after end of } \\
\text { consumption }\end{array}$ & baseline & $\begin{array}{l}\text { after } 6 \text { weeks } \\
\text { of } \\
\text { consumption }\end{array}$ & $\begin{array}{ll}2 & \text { months } \\
\text { after end of } \\
\text { consumption }\end{array}$ & baseline & $\begin{array}{l}\text { after } 6 \text { weeks } \\
\text { of } \\
\text { consumption }\end{array}$ & $\begin{array}{ll}2 & \text { months } \\
\text { after end of } \\
\text { consumption }\end{array}$ \\
\hline Mean & 135.50 & 131.83 & 141.43 & 4.14 & 4.27 & 4.45 & 96.12 & 94.87 & 98.89 \\
\hline \pm SD & 1.43 & 4.02 & 1.57 & 0.23 & 0.20 & 0.24 & 1.32 & 2.62 & 2.45 \\
\hline Max & 139.00 & 142.00 & 144.00 & 4.65 & 4.82 & 4.88 & 99.30 & 101.80 & 106.30 \\
\hline Min & 133.00 & 125.00 & 138.00 & 3.68 & 3.95 & 3.90 & 93.80 & 91.00 & 95.00 \\
\hline Mod & 135.00 & 129.00 & 141.00 & 4.17 & 4.29 & 4.44 & 96.60 & 95.10 & 100.30 \\
\hline Med & 135.00 & 131.00 & 141.00 & 4.17 & 4.28 & 4.44 & 96.20 & 94.35 & 98.70 \\
\hline$P$ & $<0.001 * * * a$ & $<0.001 * * * \mathrm{~b}$ & $<0.001 * * * \mathrm{c}$ & $0.0045^{* * a}$ & $<0.001 * * * \mathrm{~b}$ & $<0.001 * * * \mathrm{c}$ & $0.0220 * \mathrm{a}$ & $<0.001 * * * \mathrm{~b}$ & $<0.001 * * * \mathrm{c}$ \\
\hline
\end{tabular}


Three meta-analyses of randomized controlled intervention studies (RCT) (Midgley et al., 1996; Cutler et al., 1997; Graudal et al., 1998) reveals that a reduction in sodium intake - over periods ranging from days to a few years lowers BP. However, the individual BP responses to a reduction in sodium intake vary considerably among groups. Midgley et al. (1996) and Graudal et al. (1998) concluded that reduced sodium intake in normotensive persons had no impact on diastolic blood pressure (DBP). The INTERSALT study (Stamler 1997), an epidemiological study of 10079 men and women aged 20-59 years from 32 countries, indicated that an increase in sodium intake of $100 \mathrm{mmol}$ per $24 \mathrm{~h}$ was associated with an increase in both systolic and diastolic blood pressure (SBP)/(DBP) of approximately 3-6/0-3 mmHg. In the TONE study (Whelton $\boldsymbol{e}$ al., 1998), carried out in persons with hypertension aged 60-80 years, a moderate reduction in sodium intake of about $40 \mathrm{mmol}$ per $24 \mathrm{~h}$ during 29 months elicited an approximately $30 \%$ decrease in need for antihypertensive medication. Epidemiological studies have shown a positive association between dietary salt intake, blood-pressure levels and the prevalence of hypertension. Most intervention trials indicate that a reduction in salt intake significantly reduces both systolic and diastolic blood pressure. This effect is more evident in hypertensive, diabetic, obese and elderly subjects, and while it is less evident in normotensive people (Riccardi et al., 2011; Weinberger, 1996). In $65 \%$ of all GF foods, low sodium content was observed (defined as <120 mg/100 g) (Missbach et al., 2015). The response to salt intake reduction is highly variable among individuals and this different response may be modulated by genetic factors (Riccardi et al., 2011)

\section{Potassium}

Observational studies have demonstrated an inverse relationship between potassium intake and BP (Intersalt Cooperative Research Group, 1988). The mean potassium level increased significantly $(P<0.01)$ after consumption of GF bakery products compared to the first sampling and increased also after 2 months after end of the consumption of GF products $(P<0.001)$. We found the mean potassium levels of the group in the range of reference values during study (3.5$5.1 \mathrm{mmol}^{-1}$ ). Oral potassium supplementation (586 participants) significantly lowered SBP $(5 \times 9 \mathrm{mmHg})$ and DBP $(-3 \times 4 \mathrm{mmHg})$. The reductions in BP were greater in hypertensive than in normotensive individuals (Whelton et al., 1995) Analyses from trials of hypertension prevention showed that the sodiumpotassium ratio was associated with increased risk of cardiovascular disease in a dose-response relationship (Cook et al., 2009), providing complementary evidence for the adverse association between sodium chloride intake and cardiovascular disease. Epidemiological studies show an inverse correlation between blood-pressure levels and potassium intake. Almost all of the intervention trials performed have shown a significant reduction in systolic and diastolic blood pressure with potassium supplementation. Again, as for salt, this effect is more evident in hypertensive than in normotensive people and in studies where participants were accustomed to high salt intake. Potassium may act on blood-pressure regulation through its natriuretic effect on its possible effect on vascular smooth-muscle cells. The daily dietary recommended intake for potassium is generally $120 \mathrm{mmol}$ per day (4.7 g per day) (Riccardi et al., 2011).

\section{Dietary Assessment}

Several studies present in the literature have described excessive fat and protein intake, and reduced intake of carbohydrates and fiber in GF diets, which together are determining factors in cardiovascular disease risk (Miranda et al., 2014).

We were interested in how our health respondents eat besides consumption of gluten-free bakery products and how they receive sodium and potassium from the diet. We evaluated the nutritional protocols of the study participants and we focused on assessment the intake of energy, proteins, carbohydrates, fats and also sodium and potassium as minerals. We compared their intake with nutritional recommendations for Slovak population (Kajaba et al., 2015; Table 4).

Table 4 Compliance with the standard for nutrient intake

\begin{tabular}{lllllll}
\hline \multicolumn{3}{c}{ Compliance with the standard for } & & & \\
\hline & $\begin{array}{l}\text { Energy } \\
(\boldsymbol{\%})\end{array}$ & $\begin{array}{l}\text { Carbohydrates } \\
(\mathbf{\%})\end{array}$ & $\begin{array}{l}\text { Lipids } \\
(\boldsymbol{\%})\end{array}$ & $\begin{array}{l}\text { Proteins } \\
(\boldsymbol{\%})\end{array}$ & $\begin{array}{l}\text { Potassium } \\
(\boldsymbol{\%})\end{array}$ & $\begin{array}{l}\text { Sodium } \\
(\boldsymbol{\%})\end{array}$ \\
\hline Mean & 87.9 & 62.2 & 124.1 & 133.2 & 53.7 & 253.5 \\
\hline Max & 294.3 & 150.9 & 296.5 & 302.2 & 128.6 & 728.6 \\
\hline Min & 31.7 & 21.7 & 43.5 & 48.9 & 17.6 & 69.1 \\
\hline
\end{tabular}

The average energy intake of our respondents was $1759.6 \mathrm{~kJ}$ that was lower than the recommended value $(96000 \mathrm{~kJ})$ and the carbohydrate intake was on average $142.32 \mathrm{~g}$ and also lower than the recommendation (372.8 g). Compliance with the standard for energy intake was $87.9 \%$ and for carbohydrates $62.2 \%$. Our respondents, on the other hand, received more protein and fat than recommended. The current protein intake was $69.01 \mathrm{~g}$ (recommendation $53.13 \mathrm{~g}$ ) and fat intake was $80.67 \mathrm{~g}$ compared to the recommended value of $65.5 \mathrm{~g}$. There is a trend that shows an increase in consumption of all macronutrients and consequently of total energy intake. This pattern is also present in several studies that refer the GFD to be associated with high protein and lipid intake (Dickey and Kearney, 2006; Martin et al., 2013; Zuccotti et al., 2013). However, this imbalance cannot be consider only for $\mathrm{CD}$ children, since exits a large difference between the nutritional recommendations and the actual consumption of protein reported for general population (Soares $\boldsymbol{e t}$ al., 2017). Potassium intake from food was only $2405.95 \mathrm{mg}(53.7 \%)$ which was about $2094.06 \mathrm{mg}$ less than the recommended value $(4500 \mathrm{mg})$. From the evaluation of nutritional protocols we also found excessive sodium intake (3929.64 $\mathrm{mg}$ ) from the consumed food compared to the recommended intake of $1500 \mathrm{mg}(253.5 \%)$ but did not correspond to the observed levels of sodium in the blood that were meeting with the reference values and did not affect blood pressure of the participants.

The authors of the prospective cohort study report that the avoidance of dietary gluten may result in a low intake of whole grains, which are associated with cardiovascular benefits. The promotion of gluten-free diets for the purpose of coronary heart disease prevention among asymptomatic people without celiac disease should not be recommended (Lebwohl et al., 2017).

\section{CONCLUSION}

In our study we found that six-week consumption of gluten-free bread and bakery products had an non-significant effect on blood pressure as a major factor for development of cardiovascular disease, but had a significant influence on reduction of serum sodium and chloride level and a significant effect on increase in blood serum potassium level $(P<0.001)$. Increased sodium intake from the diet has not been shown to elevation of sodium in the blood. The overall effect of bread and bakery consumption on the hypertension development depends on many factors, such as the composition of the bread and bakery products and the presence of gluten-
Acknowledgments: This study was supported by the Grant agency of Slovak University of Agriculture in Nitra no. 01-GA SPU-17, by Union of Industrial Bakers of Slovakia and by the project KEGA no. 007SPU-4/2017.

\section{REFERENCES}

BECK, M., JEKLE, M., BECKER, T. 2012. Sodium chloride - sensory, preserving and technological impact on yeast-leavened products. Int. J. Food Sci. Technol. 47, 1798-1807. https://doi:10.1111/j.1365-2621.2012.03048.x

BRITES, L.T.G. F., SCHMIELE, M., STEEL, C. J. 2018. Gluten-Free Bakery and Pasta Products. Alternative and Replacement Foods. A volume in Handbook of Food Bioengineering, p. 385-410. https://doi.org/10.1016/B978-0-12-8114469.00013-7

BUTTRISS, J. 2017. Are gluten-free diets harmful for non-coeliacs? (Online) https://www.foodmanufacture.co.uk/Article/2017/07/01/Are-gluten-free-dietsharmful-for-non-coeliacs

CAUVAIN, S.P. 2007. Reduced salt in bread and other baked products. In: Kilcast, D., Angus, F. (Eds.), Reducing Salt in Foods: Practical Strategies. Woodhead Publishing Ltd., UK, pp. 283-295. https://doi.org/10.1533/9781845693046.3.283

COOK, N.R., OBARZANEK, E., CUTLER, J.A., BURING, J.E., REXRODE, K.M., KUMANYIKA, S.K., APPEL, L.J., WHELTON, P.K. 2009. Joint effects of sodium and potassium intake on subsequent cardiovascular disease: the Trials of Hypertension Prevention follow-up study. Arch. Intern. Med. 169, 32e40 https://doi:org/10.1001/archinternmed.2008.523

CUTLER, J.A., FOLLMANN, D., ALLENDER, P.S. 1997. Randomized trials of sodium reduction: an overview. American Journals of Clinical Nutrition 65 (Suppl.), p.643-651. https://doi.org/10.1093/ajcn/65.2.643S

DICKEY, W., KEARNEY, N. 2006. Overweight in celiac disease: Prevalence, clinical characteristics, and effect of a gluten-free diet. American Journal of Gastroenterology. 101: 2356-2359. https://doi:10.1111/j.15720241.2006.00750.x

EUROPEAN INSTITUTE OF ONCOLOGY. 2008. Food Composition Database for Epidemiological Studies in Italy, Version 2008 [Online] http://www.ieo.it/bda

GAŽAROVÁ, M., CHLEBOVÁ, Z., KOPČEKOVÁ, J., LENÁRTOVÁ, P., HOLOVIČOVÁ, M. 2018. The influence of gluten-free bakery products consumption on selected anthropometric parameters. In Potravinarstvo Slovak 
Journal of Food Science [online], vol. 12, 2018, no. 1, p. 761-769. ISSN 13370960. https://doi.org/10.5219/861

GRACE-FARFAGLIA, P. 2015. Bones of contention: bone mineral density recovery inceliac disease - a systematic review, Nutrients, 7, 2015, 3347-3369. https://doi.org/10.3390/nu7053347

GRAUDAL, N.A., GALLØE, A.M., GARRED, P. 1998. Effects of sodium restriction on blood pressure, renin, aldosterone, catecholamines, cholesterols, and triglyceride. a meta-analysis. Journal of the American Medical Association 279, 1383-1391. https://doi:10.1001/jama.279.17.1383

GUJRAL, N., FREEMAN, H.J., THOMSON, A.B. 2012. Celiac disease: prevalence, diagnosis, pathogenesis and treatment. World J Gastroenterol, 18:6036-6059. https://doi.org/10.3748/wjg.v18.i42.6036

HE, F.J., MACGREGOR, G.A. 2008. A comprehensive review on salt and health and current experience of worldwide salt reduction programmes. J. Hum. Hypertens. 23:363-384. https://doi:10.1038/jhh.2008.144

HERMANSEN, K. 2000. Diet, blood pressure and hypertension British Journal of Nutrition (2000), 83, Suppl. $\quad 1, \quad$ S113-S119. https://doi.org/10.1017/S0007114500001045

HUSBY, S., KOLETZKO, S., KORPONAY-SZABÓ, I.R., MEARIN, M.L. PHILLIPS, A., SHAMIR, R., TRONCONE, R., GIERSIEPEN, K., BRANSKI, D., CATASSI, C., LELGEMAN, M., MÄKI, M., RIBES-KONINCKX, C. VENTURA, A., ZIMMER, K.P. (2012). European society for pediatric gastroenterology, hepatology, and nutrition guidelines for the diagnosis of coeliac disease. Journal of Pediatrics Gastroenterology and Nutrition. 54:136-160. https://doi.org/10.1097/mpg.0b013e31821a23d0

HUTTON, T. 2002. Sodium Technological functions of salt in the manufacturing of food and drink products. Br. Food J. 104, 126e152. https://doi.org/10.1108/00070700210423635

Intersalt Cooperative Research Group. 1988. Intersalt: an International Study of electrolyte excretion and blood pressure. Results for 24 hour urinary sodium and potassium excretion. British Medical Journal 297, 319-328. https://doi.org/10.1136/bmj.297.6644.319

KAJABA, I. ŠTENCL, J. GINTER, E. ŠAŠINKA, M.A. TRUSKOVÁ, I. GAZDÍKOVÁ, K. HAMADE, J. BZDÚCH, V. 2015. Odporúčané výživové dávky pre obyvatel'stvo SR (9. revízia). In Vestník MZ SR 2015, 63, čiastka 4-5, s. $17-28$.

KIM, H.S., PATEL, K.G., OROSZ, E., et al. 2016. Time trends in the prevalence of celiac disease and gluten-free diet in the us population: results from the National Health and Nutrition Examination Surveys 2009-2014. JAMA Intern Med 2016;176:1716-7. https://doi:10.1001/jamainternmed.2016.5254

LAW, M.R. 1997. Epidemiologic evidence on salt and blood. American Journal of Hypertension, 10; 4, 42-45. https://doi.org/10.1016/S0895-7061(97)00073-3

LEBWOHL, B. CAO,Y., ZONG, G., HU,F.B., PETER H R GREEN, P. HR., NEUGUT,A.I., RIMM, E.B., SAMPSON, L., DOUGHERTY, L.W. GIOVANNUCCI, E., WILLETT, W.C., SUN,Q., CHAN, A.T. 2017. Long term gluten consumption in adults without celiac disease and risk of coronary heart disease: prospective cohort study. BMJ; 357:j1892. http://dx.doi.org/10.1136/bmj.j1892

LUDVIGSSON, J.F., RUBIO-TAPIA, A., VAN DYKE, C.T., MELTON, L.J., ZINSMEISTER, A.R., LAHR, B.D., MURRAY, J.A. 2013. Increasing incidence of celiac disease in a North American population. American Journal of Gastroenterology. 108:818-824. https://doi.org/10.1038/ajg.2013.60

MARTIN, J., GEISEL, T., MARESCH, C., KRIEGER, K., STEIN, J. 2013. Inadequate nutrient intake in patients with celiac disease: results from a german dietary survey. Digestion. 87: 240-246. https://doi.org/10.1159/000348850

MIDGLEY, P.J., MATTHEW, A.G., GREENWOOD, C.M., LOGAN, A.G 1996. Effects of reduced dietary sodium on blood pressure. A meta analysis of randomized controlled trials. Journal of the American Medical Association 275, 1590-1597. https://doi:10.1001/jama.1996.03530440070039

MIRANDA, J., LASA, A., BUSTAMANTEMA, CHURRUCA I., SIMON E. 2014. Nutritional differences between a gluten-free diet and a diet containing equivalent products with gluten. Plant FoodsHumNutr 69:182-187. https://doi.org/10.1007/s11130-014-0410-4

MISSBACH, B., SCHWINGSHACKL, L., BILLMANN, A., MYSTEK, A. HICKELSBERGER, M., BAUER, G., KÖNIG, J. 2015. Gluten-free food database: the nutritional quality and cost of packaged gluten-free foods. PeerJ. (3):1337. https://doi.org/10.7717/peerj.1337

MOZAFFARIAN, D., BENJAMIN, E.J., GO, A.S., ARNETT, D.K., BLAHA, M.J., CUSHMAN, M., DE FERRANTI, S., DESPR_ES, J-P., FULLERTON, H.J., HOWARD, V.J., HUFFMAN, M.D., JUDD, S.E., KISSELA, B.M. LACKLAND, D.T., LICHTMAN, J.H., LISABETH, L.D., LIU, S., MACKEY, R.H., MATCHAR, D.B, MCGUIRE, D.K., MOHLER, R.D., E.R., MOY, C.S., MUNTNER, P., MUSSOLINO, M.E., NASIR, K., NEUMAR, R.W., NICHOL, G., PALANIAPPAN, L., PANDEY, D.K., REEVES, M.J., RODRIGUEZ, C.J., SORLIE, P.D., STEIN, J., TOWFIGHI, A., TURAN, T.N., VIRANI, S.S., WILLEY, J.Z., WOO, D., YEH, R.W., TURNER, M.B. 2015. Heart Disease and Stroke Statistics e At-a-glance. American Heart Association Statistics Committee and Stroke Statistics Subcommittee https://doi:org:10.1161/CIR.0000000000000152
MULDER, C.J., WIERDSMA, N.J., BERKENPAS, M., JACOBS M.A., BOUMA, G. 2015. Preventing complications in celiac disease: our experience with managing adult celiac disease. Best Practice \& Research Clinical Gastroenterology. 29:459-468. https://doi.org/10.1016/j.bpg.2015.05.006 PARLAMENTO EUROPEO E DEL CONSIGLIO, REGOLAMENTO (CE) N 1924/2006. Gazz Uff Unione Eur L404:9-25. https://eur-lex.europa.eu/legalcontent/IT/TXT/?uri=celex\%3A32006R1924

PELLEGRINI, N., AGOSTONI, C. 2015. Nutritional aspects of gluten-free products (review). (wileyonlinelibrary.com) https://doi.org/10.1002/jsfa.7101 PITCHAI B., KHIN MAUNG-U, GOWRAGANAHALLI J. (2016). Prevalence and prevention of cardiovascular disease and diabetes mellitus. Pharmacological Research 113 (2016) 600-609. http://dx.doi.org/10.1016/j.phrs.2016.09.040 POWLES, J., FAHIMI, S., MICHA, R., KHATIBZADEH, S., SHI, P., EZZATI, M., ENGELL, R.E., LIM, S.S., DANAEI, G., MOZAFFARIAN, D. 2013 Global, regional and national sodium intakes in 1990 and 2010: a systematic analysis of $24 \mathrm{~h}$ urinary sodium excretion and dietary surveys worldwide. BMJ Open, 3, 12, e003733 http://dx.doi.org/10.1136/bmjopen-2013-003733

RICCARDI, G., RIVELLESE, A.A., WILLIAMS, CH.M. The Cardiovascular System. In Lanham-New A.A., Macdonald I.A., Roche H.M. 2011. Nutrition and Metabolism. $2^{\text {nd }}$ edition. The Nutrition Society, 2011, p.247-271. ISBN 978-14051-6808-3. https://doi.org/10.1002/9781444327779.ch11

SILOW, CH., AXEL, C., ZANNINI, E. ELKE K. ARENDT E. K. 2016. Current status of salt reduction in bread and bakery products. Journal of Cereal Science, 2016; 72: 135-145. https://doi.org/10.1016/j.jcs.2016.10.010

SOARES, P., LEMOS, P.S., PIRES, A. M., CAVACO DE SOUSA, A. C. 2017. Celiac Disease and Gluten-free Diet in Portuguese Children - An Anthropometric Marker Contribution Assessment. International Journal of Celiac Disease, 5, (2), 62-68. https://doi.org/10.12691/ijcd-5-2-5

STAMLER, J. 1997 The INTERSALT Study: background, methods, findings, and implications. American Journal of Clinical Nutrition, 65 (2), p.626-642. https://doi.org/10.1093/ajcn/65.2.626S

SUCHÁ, V., JURGOŠ, L., DOSTÁLOVÁ, K., MÓRICOVÁ, Š. 2015. Aktuálny pohl'ad na Celiakiu. Via pract. 12(1):22-28. ISSN 1339-424X. https://doi.org/10.1016/s1878-7649(15)30202-3

TAYLOR, J., ROSELL. C. 2016. Functionality of cereal based non-gluten dough systems. Journal of Cereal Science, 67, 1 . https://doi.org/10.1016/j.jcs.2015.10.001

WARDENER, H. DE, MACGREGOR, G., 2002. Harmful effects of dietary salt in addition to hypertension. J. Hum. Hypertens. 16, 213-223. https://doi:10.1038/sj.jhh.1001374

WEINBERGER, M.H. 1996. Salt sensitivity and blood pressure in humans Hypertension.; 27(3): 481-490. https://doi.org/10.1161/01.HYP.27.3.481

WHELTON, P.K., APPEL, J.L., ESPELAND, M.A., APPLEGATE, W.B. ETTINGER, W.H., KOSTIS, J.B., KUMANYIKA, S., LACY, C.R., JOHNSON K.C., FOLMAR, S., CUTLER, J.A., for the TONE Collaborative Research Group. 1998. Sodium reduction and weight loss in the treatment of hypertension in older persons: a randomized controlled trial of nonpharmacological interventions in the elderly (TONE). Journal of the American Medical Association 279, 839-846. https://doi:10.1001/jama.279.11.839

WHELTON, P.K., BURING, J., BORHANI, N.O., COHEN, J.D., COOK, N., CUTLER, J.A., KILEY, J.E., KULLER, L.H., SATTERFIELD, S., SACKS F.M. 1995. The effect of potassium supplementation in persons with a highnormal blood pressure. Results from Phase I of the Trials of Hypertension Prevention (TOHP). Trials of Hypertension Prevention (TOHP) Collaborative Research Group. Annals of Epidemiology 5, 85-95. https://doi.org/10.1016/10472797(94)00053-V

WU, J.H., NEAL, B., TREVENA, H., CRINO, M., STUART-SMITH, W., FAULKNER-HOGG, K., YU LOUIE, J.C., DUNFORD, E. 2015. Are glutenfree foods healthier than non-gluten-free foods? An evaluation of supermarket products in Australia. Br $J$ Nutr. 14;114(3):448-54 https://doi.org/10.1017/S0007114515002056

ZUCCOTTI, G., FABIANO, V., DILILlO, D., PICCA, M., CRAVIDI, C., BRAMBILLA, P. 2013. Intakes of nutrients in Italian children with celiac disease and the role of commercially available gluten-free products. Journal of Human Nutrition and Dietetics. 26(5): 436-444. https://doi.org/10.1111/jhn.12026 